\title{
A Study on the Customer Segmentation based on Psycho Graphics towards the Eco Label Awareness among the Indian Food and Grocery Retailing Customers
}

\author{
V. Sravani Chari ${ }^{\text {a }}$, Dr.M. Siva Koti Reddy ${ }^{\text {b }}$ \\ a'Research Scholar, Vignan's Foundation for Science, Technology and Research, Vadlamudi, Guntur, Andhra Pradesh, India. \\ bAssociate Professor, Vignan's Foundation for Science, Technology and Research, Vadlamudi, Guntur, Andhra Pradesh, India. \\ a sravanivangi@gmail.comb shiva.manukonda@gmail.com
}

Article History: Received: 10 November 2020; Revised 12 January 2021 Accepted: 27 January 2021; Published online: 5 April 2021

\begin{abstract}
This paper is emphasised to understand the psycho-graphic segmentation of online food and grocery retailing customers towards the eco label awareness. The study considered VALS (Values and life styles) model as the base for this paper. The better psychological understanding helps the marketers to served them in a better way. Hence, the data has been collected from the Indian customers who preferred online to purchase their food and grocery products. There are 117 samples drawn for this study and applied cross-tabulation analysis. The results of the study are provided elaborately in the paper

Keywords: Psychographic Segmentation; Values and Life Styles; Indian Food and Grocery retailing; Demographics; Eco label awareness
\end{abstract}

\section{Introduction}

The concept of marketing segmentation is an interesting concept for both the customers and the marketers (Domowitz, Glen, \&Madhavan, 2012; Barat, S. 2010; Bauer et al., 2012; De Mooji, M. 2010, Sivakoti Reddy, M. 2019). The main reason for following mass advertising by the marketers is that one item for consumption was used to convince huge amount of people and same built-up and communiqué strategies are implemented for similar Product (Dickson \&Ginter, 1987; Fuller et al., 2008). In the recent past the marketers' sense that if they deflect mass markets manufactured goods as tiny goods and set up multiple goods then they will please their consumers in an improved manner. Begin consumer-centric goods, the aim at particular cluster of clients and initiate product for that exact group then it might not only convene their wants but also suit patrons on least price (Walsh, Hennig-Thurau, Wilkie et al., 1977; Chen et al., 2009, Sivakoti Reddy, M., Murali Krishna, S.M. (2019).

Before 1980 marketers are very much interested towards mass marketing or the promotion. Market segmentation has been evolved as a significant subject in developing, positioning, and selling products or services across the world. This process aids the marketers to target their latent patrons and to attain a suitable positioning. The main issue for the organizations in the market segmentation is to efficiently deal with the construction of heterogeneity in consumer needs and wants and to target the specific segments of consumers. The concerned segments replicate geographic groupings or groups of entities and comprise of probable customers who are expected to show similar responses to marketing energies (Sivakoti Reddy, M., Venkateswarlu, N. (2019).

The demographic segmentation is the procedure to divide the whole market in to small groups which can be traced based on the factual and physical data. Usually the factors such as, gender, age, marital status, family size, monthly household income, religion, nationality and race are considered to be the demographic factors in any research. Specifically, in the marketing research, the researchers consider that the demographics are easy to understand well the consumer markets and also easy to assess. Geographic segmentation involves choosing probable markets with respect to their location. The main aspect in geographic segmentation are the climatic changes, availability of natural resources, density of the population in the concerned markets etc (Addela, S., Sivakoti Reddy, M. (2019). The customer markets may be segmented into various regions because one or more of these characteristics would be differentiate consumers from one place to the other one. The individual purchase patterns and behaviours can be observed and assessed for the behavioural segmentation. Under this behavioural segmentation, the marketers will be in a position to understand the customers' specific buying behaviour. The customer behaviour can be assessed based on the shopping frequency and the basket volume of the purchase (Vijaya, P., Sivakoti Reddy, M. 2019, Sivakoti Reddy, M., Naga Bhaskar, M., Nagabhushan, A.(2019), Manukonda et al. (2019). 


\section{Review of Literature}

The literature on marketing segmentation and the marketing modelling is huge. Wind (1978) is a standard article which explains the concept of market segmentation which is the study of previous to the rigorous investigate keen on exact segmentation areas. The authors such as Myers and Tauber (1976 \&1977) and Wilkie and Cohen (1977) also provided the abundant literature over the marketing segmentation research. The studies of Barnett (1969) and Yankelovich (1964); Worcester et al., (1969); Ziff, R., (1971) are considered to be pioneering studies in the concept of marketing segmentation. The main intention of the market segmentation is to observe the actual existence of segmentation of the customers. In other words, the supposition is that the market is not completely standardized.

The notion of "lifestyle" is efficaciously used in the domain of marketing communication to effect the ingesting outlines of the customers of the concerned organizations. It became the basis for a distinct type of segmentation research named "psychographics", which characteristically uses extemporaneous AIO (Activities, Interests and Opinions) surveys employing cluster analysis, and which can navigate the marketers towards most successful lifestyle patterns. Lifestyle and psychographic examines denote procedure in which customers coherent themselves in social and cultural environments. Groups, community and substantial others influence consumers' lifestyles and value systems. They are also formed by the generation to which the customers belong, for instance, Gen X or Gen Y (DuPreez et al., 2007). Furthermore, the marketers may also try to analyse the better market needs by understanding the livings standards of the customers, spending capacity and also the purchase decision making process (Du Preez et al., 2007).

\section{Research Gap}

The market segmentation with respect to psychographic is difficult to explain as they are not clearly defined and not possible to measure accurately but, the current research is emphasized to investigate the role of psychographic segmentation (Beatty et al., 1988). Looking at the immense opportunity that specifically in online marketing segment, along with the need for the marketers in the present online marketing, the growth of online shopping avenues in the Indian e-commerce has been below-par, hence the study attempts to unearth the moderating impact of cognitive bias over the psychographic segmentation of the customers on eco label awareness among the Indian online apparel segment.

\section{Research Methodology}

The study considered the Indian customers who purchase the food and grocery through online portals such as, amazon and flipkart. A structured questionnaire is prepared and the data has been collected through the telephonic interview. In order to collect the required data the research team approached the respondents through telephone and collected the data. The research team approached totally 200 respondents and out of which 117 respondents' positively and participated in the survey. Hence, we concluded that the sample size of the study is 117.

\section{Data Analysis}

\section{Socio-economic, Demographic and Geographic Characteristics of the Respondents}

There are totally 117 respondents participated in this survey and out of which 72 (61.5 percent) members are male and 45 members (38.5 percent) are female. It is observed that the lowest age of the customers is 20 years and the highest age is found to be 68 years. The mean age of the participants is 35.59 years and the standard deviation is found to be 11.46 years. With respect to the marital status of the participants, it is denoted that majority of them are married i.e 108 (92.3 percent) and merely 9 members ( 7.7 percent) are found to be un-married. The concerned data of this study has been collected from different segments of the society such as, housewives, employees, business persons, retired employees and students. This may help to understand the real perceptions of the customers. This data is drawn from 12 (10.3 percent) housewives, 54 (46.2 percent) employees, 29 (24.8 percent) business persons, 11 (9.4 percent) retired employees and 11 (9.4 percent) students.

Further, the researcher also tried to collect the data from the respondents who has different educational qualification. The data designated that, there are 10 (8.5 percent) of the respondents have either SSC or Diploma as their educational qualification. There are 52 members (44.4 percent) haveBachelors Degree as their educational qualification and 55 members (47 percent) have Post-Graduation as their educational qualification. The study also revealed that the lowest monthly house-hold income of the respondents is Rs 16,000 and the highest monthly house-hold income is Rs 65,000. The mean house-hold income is denoted as Rs 32,800 and the standard deviation is found to be Rs 10,337. The demographic details of the respondents is presented in table -3 of Appendix of this research paper. 


\section{Cross Tabulation Analysis}

Cross-tabulation analysis is the best method to understand the customers' demographic factors and the other aspects related to the marketing studies. In this research paper, the researcher applied the cross-tabulation analysis between the demographic characteristics of the customers and the research questions of online purchase frequency of the customers and their preferred store choice among the different avenues such as, amazon, flipkart, snapdeal, paytm and myntra. The detailed analysis is as follows:

\section{Cross tabulation between the shopping frequency and the demographic characteristics}

The cross-tabulation analysis depicts many interesting facts. The statistical analysis stated that among the total 72 of male population, 17 (23.61 percent) members stated that they will buy extremely often, 15 (20.83 percent) respondents disclosed that, they will buy quite often, 16 (22.22 percent) members who participated in the survey stated that they will moderately often purchase the food and grocery through online. 14 (19.45 percent) members of the male participants stated that they will purchase slightly often and only 10 (13.88 percent) male participants mentioned that they not at all often purchase their apparels through online. With respect to the total 45 women respondents, 9 (20 percent) members stated that they extremely often purchase, 7 (15.55 percent) members discloses that they purchase quite often, 13 (28.89 percent) participants elicited that they will purchase moderately often, 8 (17.77 percent) customers disclosed that they will purchase slightly often and 8 (17.77 percent) members revealed that they not at all often purchase the food and grocery through online. The Chi-Square value of this statistic is 1.382 , the degree of freedom is 4 and the $\mathrm{p}$ value is found to be 0.847 . This phenomenon clearly indicates that there is no significant association between the gender and purchase frequency.

The study consists of more no of respondents who are married. The cross tabulation results of the marital status revealed that, among the total 108 married respondents 25 (23.14 percent) members stated that they extremely often purchase through online, 20 (18.51 percent) members disclosed that they quite often purchase the food and grocery through online, 27 ( 25 percent) customers narrated that they will moderately often purchase the food and grocery through online, 21 (19.45 percent) members stated that they will purchase slightly often and 15 (13.88 percent) customers revealed that they not at all often purchase their apparels through online avenues. Among the total 9 respondents, 1 (11.11 percent) member said extremely often purchase apparels through online, 2 (22.22 percent) customers disclosed that they quite often purchase the food and grocery, 2 (22.22 percent) members revealed that they moderately often purchase the food and grocery, 1 (11.11 percent) participant denoted to slightly often purchase the food and grocery, 3 (33.33 percent) members disclosed that they not at all often purchase their apparel requirements through online. The Chi-Square value of the concerned statistic is found to be 2.977, degrees of freedom is 4 and the $\mathrm{p}$ value if found to be 0.562 . It denotes that there is no significant association between the marital status of the respondent and the purchase frequency of the customers.

The cross tabulation between the occupation of the respondents and the frequency of purchase disclosed various findings. It is observed that there are 12 housewives in the study and among them 2 (16.66 percent) members disclosed that they extremely often purchase, 2 (16.66 percent) respondents stated that they quite often purchase, 3 (25 percent) participants mentioned that they moderately often purchase, 3 ( 25 percent) members denoted that they slightly often purchase and 2 (16.66 percent) members stated that they not at all often purchase the food and grocery through online. The major chunk of the respondents are identified as employees and their number is 54. Among them, 16 (29.62 percent) members stated that they purchase extremely often, 6 (11.11 percent) participants disclosed that they will purchase quite often, 14 (25.92 percent) respondents expressed that they will purchase moderately often, 10 (18.51 percent) members elicited that they purchase slightly often and only 8 (14.81 percent) members stated that they not at all purchase their apparel products through online. There are 29 members who participated in this survey are operating their own business. Among them, 2 (6.89 percent) members said they will purchase extremely often, 9 (31.03 percent) respondents stated that they will purchase quite often, 9 (31.03 percent) other members disclosed that they moderately often purchase, 5 (17.24 percent) participants revealed that they slightly often purchase the food and grocery through online and 4 (13.79 percent) members stated that they not at all often purchase their apparel requirements through online avenues. Within the segment of retired persons, 3 (27.27 percent) members of the study stated they extremely often purchase, 2 (18.18 percent) participants revealed that they moderately often purchase, 3 (27.27 percnet) members denoted that they slightly often purchase and only 1 (9.09 percent) participant opted for not at all often purchase the food and grocery through online avenues. There are 11 students participated in this study and among them, 3 (27.27 percent) members disclosed that they purchase extremely often, 3 (27.27 percent) members revealed that they will purchase quite often and another 3 members stated that they never at all often purchase their apparel through online. The statistic results revealed that the Ch-Square value is 13.669 , degrees of freedom is 16 and the $\mathrm{p}$ value is found to be 0.623 . Hence, we conclude that there is significant association between the occupation of the respondents and their purchase frequency. 
The primary data of this study is the conglomeration of various participants who has different levels of qualifications. Among the respondents who has SSC or Diploma as their educational qualification, 2 (20 percent) members stated they quite often purchase the products, 7 (70 percent) respondents disclosed that they will moderately often purchase, and only one participant (10 percent) denoted the slightly often purchase of their apparels through online. Within the respondents who have Degree as their educational qualification, 12 (23.07 percent) members disclosed that they extremely often purchase, 12 (23.07 percent) respondents revealed that they quite often purchase, 13 (25 percent) participants denoted that they moderately often purchase, 6 (11.53 percent) members elicited that they slightly often purchase, and 9 respondents expressed their opinion as they not at all often purchase through online. Among the post graduates, 14 (23.07 percent) members stated that they extremely often purchase, 8 ( 14.54 percent) participants disclosed that they purchase quite often, 9 (16.36 percent) respondents denoted that they purchase moderately often, 15 (27.27 percent) members expressed that they purchase slightly often and only 9 (16.36 percent) members stated that they not at all often purchase the food and grocery through online. The Chi-Square results elicited the coefficient value is 19.031, degrees of freedom is 8 and $\mathrm{p}$ value is found to be 0.015 . Based on this we conclude that there is a significant association between the educational qualification of the respondents and their purchase frequency. The concerned details are presented in table -1 .

Table -2 : Cross-tabulation analysis over Demographic characteristics and Purchase Frequency of the Respondents

\begin{tabular}{|c|c|c|c|c|c|c|c|c|}
\hline \multicolumn{2}{|c|}{$\begin{array}{l}\text { Demographic } \\
\text { Description }\end{array}$} & \multirow{2}{*}{$\begin{array}{l}\text { Tota } \\
\mathbf{l} \\
\text { sample } \\
\mathbf{n = 1 1 5}\end{array}$} & \multirow{2}{*}{\begin{tabular}{c}
\multicolumn{1}{c}{ Extre } \\
mely \\
Often \\
17 \\
$(23.61)$
\end{tabular}} & \multirow{2}{*}{$\begin{array}{c}\begin{array}{r}\text { Quite } \\
\text { Often }\end{array} \\
\\
15 \\
(20.83)\end{array}$} & \multirow{2}{*}{$\begin{array}{c}\begin{array}{c}\text { Moder } \\
\text { ately } \\
\text { Often }\end{array} \\
16 \\
(22.22)\end{array}$} & \multirow{2}{*}{$\begin{array}{c}\begin{array}{c}\text { Slightl } \\
\mathbf{y} \text { Often }\end{array} \\
14 \\
(19.44)\end{array}$} & \multirow{2}{*}{\begin{tabular}{c}
\multicolumn{2}{c}{ Not } \\
$\begin{array}{l}\text { at all } \\
\text { Often }\end{array}$ \\
10 \\
$(13.88)$
\end{tabular}} & \multirow{3}{*}{$\begin{array}{l}\text { Sq }^{\text {Chi }} \\
\\
\begin{array}{l}1.382 \\
; 4 ; \mathrm{P}> \\
0.05\end{array}\end{array}$} \\
\hline \multirow{2}{*}{$\begin{array}{l}\text { Ge } \\
\text { nder }\end{array}$} & Male & & & & & & & \\
\hline & Female & $\begin{array}{r}45 \\
(38.5)\end{array}$ & $9(20)$ & $\begin{array}{c}7 \\
(15.55)\end{array}$ & $\begin{array}{c}13 \\
(28.88)\end{array}$ & $\begin{array}{c}8 \\
(17.77)\end{array}$ & $\begin{array}{c}8 \\
(17.77)\end{array}$ & \\
\hline \multirow{2}{*}{$\begin{array}{l}\quad \mathrm{M} \\
\text { arital } \\
\text { Status }\end{array}$} & d Marrie & $\begin{array}{l}108 \\
(92.3)\end{array}$ & $\begin{array}{c}25 \\
(23.14)\end{array}$ & $\begin{array}{c}20 \\
(18.51)\end{array}$ & $27(25)$ & $\begin{array}{c}21 \\
(19.44)\end{array}$ & $\begin{array}{c}15 \\
(13.88)\end{array}$ & \multirow{2}{*}{$\begin{array}{r}2.977 \\
P>0.05\end{array}$} \\
\hline & $\begin{array}{l}\text { Unmar } \\
\text { ried }\end{array}$ & $\begin{array}{r}9 \\
(7.7)\end{array}$ & $\begin{array}{c}1 \\
(11.11)\end{array}$ & $\begin{array}{c}2 \\
(22.22)\end{array}$ & $\begin{array}{c}2 \\
(22.22)\end{array}$ & $\begin{array}{c}1 \\
(11.11)\end{array}$ & $\begin{array}{c}3 \\
(33.33)\end{array}$ & \\
\hline \multirow{5}{*}{$\begin{array}{l}\text { Oc } \\
\text { cupati } \\
\text { on }\end{array}$} & $\begin{array}{l}\text { House } \\
\text { wife }\end{array}$ & $\begin{array}{r}12 \\
(10.3)\end{array}$ & $\begin{array}{c}2 \\
(16.66)\end{array}$ & $\begin{array}{c}2 \\
(16.66)\end{array}$ & $3(25)$ & $3(25)$ & $\begin{array}{c}2 \\
(16.66)\end{array}$ & \multirow{5}{*}{$\begin{array}{r}13.66 \\
9 ; \quad 16 ; \\
P>0.05\end{array}$} \\
\hline & yee $^{\text {Emplo }}$ & $\begin{array}{r}54 \\
(46.2)\end{array}$ & $\begin{array}{c}16 \\
(29.63)\end{array}$ & $\begin{array}{c}6 \\
(11.11)\end{array}$ & $\begin{array}{c}14 \\
(25.92)\end{array}$ & $\begin{array}{c}10 \\
(18.51)\end{array}$ & $\begin{array}{c}8 \\
(14.81)\end{array}$ & \\
\hline & ss & $\begin{array}{r}29 \\
(24.8)\end{array}$ & $\begin{array}{c}2 \\
(6.89)\end{array}$ & $\begin{array}{c}9 \\
(31.03)\end{array}$ & $\begin{array}{c}9 \\
(31.03)\end{array}$ & $\begin{array}{c}5 \\
(17.24)\end{array}$ & $\begin{array}{c}4 \\
(13.79)\end{array}$ & \\
\hline & $\begin{array}{c}\text { Retired } \\
\text { Employee }\end{array}$ & $\begin{array}{c}11 \\
(9.4)\end{array}$ & $\begin{array}{c}3 \\
(27.27)\end{array}$ & $\begin{array}{c}2 \\
(27.27)\end{array}$ & $\begin{array}{c}2 \\
(9.09)\end{array}$ & $\begin{array}{c}3 \\
(9.09)\end{array}$ & $\begin{array}{c}1 \\
(27.27)\end{array}$ & \\
\hline & $\begin{array}{ll} & \text { Studen } \\
\mathrm{t} & \end{array}$ & $\begin{array}{c}11 \\
(9.4)\end{array}$ & $\begin{array}{c}3 \\
(27.27)\end{array}$ & $\begin{array}{c}3 \\
(27.27)\end{array}$ & $\begin{array}{c}1 \\
(9.09)\end{array}$ & $\begin{array}{c}1 \\
(9.09)\end{array}$ & $\begin{array}{c}3 \\
(27.27)\end{array}$ & \\
\hline \multirow{3}{*}{$\begin{array}{l}\text { Ed } \\
\text { ucatio } \\
n\end{array}$} & $\begin{array}{l}\text { SSC/D } \\
\text { iploma }\end{array}$ & $\begin{array}{c}10 \\
(8.5)\end{array}$ & 0 & $2(20)$ & $7(70)$ & $1(10)$ & 0 & \multirow{3}{*}{$\begin{array}{l}19.03 \\
1 ; \quad 8 ; \\
P<0.05\end{array}$} \\
\hline & Degree & $\begin{array}{r}52 \\
(44.4)\end{array}$ & $\begin{array}{c}12 \\
(23.07)\end{array}$ & $\begin{array}{c}12 \\
(23.07)\end{array}$ & $13(25)$ & $\begin{array}{c}6 \\
(11.53)\end{array}$ & $\begin{array}{c}9 \\
(17.30)\end{array}$ & \\
\hline & $\begin{array}{l}\text { Post- } \\
\text { Graduatio } \\
n\end{array}$ & $\begin{array}{r}55 \\
(47.0)\end{array}$ & $\begin{array}{c}14 \\
(25.45)\end{array}$ & $\begin{array}{c}8 \\
(14.54)\end{array}$ & $\begin{array}{c}9 \\
(16.36)\end{array}$ & $\begin{array}{c}15 \\
(27.27)\end{array}$ & $\begin{array}{c}9 \\
(16.36)\end{array}$ & \\
\hline
\end{tabular}

Source: Primary Data 


\section{Cross tabulation between the shopping avenues and the demographic characteristics}

The statistical analysis stated that among the total 72 of male population, 16 (22.22 percnet) members stated that they buy in Amazon, 15 (20.83 percent) respondents disclosed that, they buy in Flipkart, 9 (12.5 percent) members who participated in the survey stated that they buy in Snapdeal. 21 (29.16 percent) members of the male participants stated that they purchase through Paytm and only 11 (15.27 percent) male participants mentioned that they purchase their apparels through Myntra . With respect to the total 45 women respondents, 9 (20 percent) members stated that they purchase through Amazon, 8 (17.77 percent) members discloses that they purchase through Flipkart, 9 (20 percent) participants elicited that they will purchase through Snapdeal, 12 (26.66 percent) customers disclosed that they will purchase through Paytm and 7 (15.55 percent) members revealed that they purchase through Myntra. The Chi-Square value of this statistic is 1.271, the degree of freedom is 4 and the $\mathrm{p}$ value is found to be 0.866 . This phenomenon clearly indicates that there is no significant association between the gender and shopping avenues.

The cross tabulation results of the marital status revealed that, among the total 108 married respondents 22 (20.37 percent) members stated that they purchase through Amazon, 22 (20.37 percent) members disclosed that they purchase through Flipkart , 18 (16.66 percent) customers narrated that they purchase through Snapdeal , 30 (27.77 percent) members stated that they will they purchase through Paytm and 16 (14.81 percent) customers revealed that they purchase their apparels through Myntra. Among the total 9 un married respondents, 3 (33.33 percent) members said they purchase through Amazon, 1 (11.11 percent) customer disclosed to purchase through Flipkart, 3 (33.33 percent) participants denoted that they use Paytm to purchase their apparels, 2 (22.22 percent) members disclosed that they use Myntra to purchase their apparel requirements through online. The Chi-Square value of the concerned statistic is found to be 2.903 , degrees of freedom is 4 and the p value if found to be 0.574 . It denotes that there is no significant association between the marital status of the respondent and the shopping avenues of the customers.

The cross tabulation between the occupation of the respondents and the shopping avenues disclosed various findings. It is observed that there are 12 housewives in the study and among them 2 (16.66 percent) members disclosed that they purchase through Amazon, 2 (16.66 percent) respondents stated that they purchase through Flipkart, 3 (25 percent) participants mentioned that they purchase through Snapdeal, 4 (33.33 percent) members denoted that they use Paytm to purchase and 1 ( 8.33 percent) member stated to purchase thorughMyntra . The major chunk of the respondents is identified as employees and their number is 54. Among them, 11 (20.37 percent) members stated that they purchase through Amazon, 9 (16.66 percent) participants disclosed that they will purchase through Flipkart, 8 (14.81 percent) respondents expressed that they will purchase through Snapdeal, 16 (29.62 percent) members elicited that they purchase through Paytm and only 10 (18.51 percent) members stated that they purchase their apparel products through Myntra. There are 29 members who participated in this survey are operating their own business. Among them, $6(20.68$ percent $)$ members said they will purchase through Amazon, 9 (31.03 percent) respondents stated that they will purchase through Flipkart, 5 (17.24 percent) other members disclosed that they purchase through Snapdeal, 6 (20.68 percent) participants revealed that they use Paytm and 3 (10.34 percent) members stated that they use Myntra to purchase their apparel requirements through online avenues. Within the segment of retired persons, 3 (27.27 percent) members of the study stated they Amazon purchase, 1 (9.09 percent) participant revealed that they use Snapdeal to purchase, 3 (27.27 percent) members denoted that they use Paytm to purchase and 2 (18.18 percent) participants opted for Myntra avenues. There are 11 students participated in this study and among them, 3 (27.27 percent) members disclosed that they purchase through Amazon, 2 (18.18 percent) members revealed that they will purchase through Flipkart and another 4 (36.36 percent) members stated that they purchase their apparel through Paytm and 2 (18.18 percent) members disclosed that they use Myntra to purchase their apparels. The statistic results revealed that the $\mathrm{Ch}$ Square value is 8.225 , degrees of freedom is 16 and the $\mathrm{p}$ value is found to be 0.942 . Hence, we conclude that there is significant association between the occupation of the respondents and their shopping avenues.

The primary data of this study is the conglomeration of various participants who has different levels of qualifications. Among the respondents who has SSC or Diploma as their educational qualification, 5 members use Amazon as the shopping avenue to purchase through online, 1 member stated they purchase through Flipkart, 1 respondent disclosed that they purchase through Snapdeal, and 2 participant denoted that they use Paytm to purchase their apparels through online. Within the respondents who have Degree as their educational qualification, 7 members disclosed that they use Amazon to purchase, 10 respondents revealed that they purchase through Flipkart, 11 participants denoted that they use Snapdeal to purchase, 18 members elicited that they use Paytm to purchase, and 6 respondents expressed their opinion as they use Myntra to purchase through online. Among the post graduates, 13 members stated that they use Amazon to purchase, 12 participants disclosed that they purchase through Flipkart, 6 respondents denoted that they purchase through Snapdeal, 13 members expressed that they purchase through Paytm and only 11 members stated that they use Myntra. The Chi-Square results elicited the coefficient value is 10.983 , degrees of freedom is 8 and $p$ value is found to be 0.203 . Based on this we conclude 
that there is no significant association between the educational qualification of the respondents and their shopping avenues. The details are presented in table -2 .

Table - 6 : Cross-tabulation analysis over Demographic characteristics and Online Shopping Avenues

\begin{tabular}{|c|c|c|c|c|c|c|c|c|}
\hline \multicolumn{2}{|c|}{$\begin{array}{l}\text { Demographic } \\
\text { Description }\end{array}$} & \multirow{2}{*}{$\begin{array}{c}\begin{array}{r}\text { Total } \\
\text { sample } \\
\mathbf{n = 3 1 5}\end{array} \\
72 \\
(61.5)\end{array}$} & \multirow{2}{*}{$\begin{array}{c}\text { on Amaz } \\
16 \\
(22.22)\end{array}$} & \multirow{2}{*}{$\begin{array}{c}\text { Flipkart } \\
15 \\
(20.83)\end{array}$} & \multirow{2}{*}{$\begin{array}{ll}\text { Snapdea } \\
9(12.5)\end{array}$} & \multirow{2}{*}{$\begin{array}{c}\text { Paytm } \\
21 \\
(29.16)\end{array}$} & \multirow{2}{*}{$\begin{array}{c}\begin{array}{c}\text { Myntra } \\
\text {.com }\end{array} \\
11 \\
(15.27)\end{array}$} & \multirow{3}{*}{ 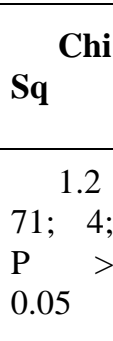 } \\
\hline \multirow{2}{*}{ er } & Male & & & & & & & \\
\hline & Female & $\begin{array}{r}45 \\
(38.5)\end{array}$ & $9(20)$ & $8(17.77)$ & $9(20)$ & $\begin{array}{c}12 \\
(26.66)\end{array}$ & $\begin{array}{c}7 \\
(15.55)\end{array}$ & \\
\hline \multirow{2}{*}{$\begin{array}{l}\text { Marit } \\
\text { al Status }\end{array}$} & Married & $\begin{array}{l}108 \\
(92.3)\end{array}$ & $\begin{array}{c}22 \\
(20.37)\end{array}$ & $\begin{array}{c}22 \\
(20.37)\end{array}$ & $\begin{array}{c}18 \\
(16.66)\end{array}$ & $\begin{array}{c}30 \\
(27.77)\end{array}$ & $\begin{array}{c}16 \\
(14.81)\end{array}$ & \multirow{2}{*}{$\begin{array}{l}2.9 \\
03 ; \quad 4 ; \\
P>0.05\end{array}$} \\
\hline & $\begin{array}{l}\text { Unmarri } \\
\text { ed }\end{array}$ & $9(7.7)$ & $\begin{array}{c}3 \\
(33.33)\end{array}$ & $1(11.11)$ & 0 & $\begin{array}{c}3 \\
(33.33)\end{array}$ & $\begin{array}{c}2 \\
(22.22)\end{array}$ & \\
\hline \multirow{5}{*}{$\begin{array}{l}\text { Occu } \\
\text { pation }\end{array}$} & $\begin{array}{l}\text { House } \\
\text { wife }\end{array}$ & $\begin{array}{r}12 \\
(10.3)\end{array}$ & $\begin{array}{c}2 \\
(16.66)\end{array}$ & $2(16.66)$ & $3(25)$ & $\begin{array}{c}4 \\
(33.33)\end{array}$ & $1(8.33)$ & \multirow{5}{*}{$\begin{array}{r}8.2 \\
25 ; 16 \\
\mathrm{P}>0.05\end{array}$} \\
\hline & ee & $\begin{array}{r}54 \\
(46.2)\end{array}$ & $\begin{array}{c}11 \\
(20.37)\end{array}$ & $9(16.66)$ & $8(14.81)$ & $\begin{array}{c}16 \\
(29.62)\end{array}$ & $\begin{array}{c}10 \\
(18.18)\end{array}$ & \\
\hline & $\begin{array}{ll} & \text { Busines } \\
\mathrm{s} & \end{array}$ & $\begin{array}{r}29 \\
(24.8)\end{array}$ & $\begin{array}{c}6 \\
(20.68)\end{array}$ & $9(31.03)$ & $5(17.24)$ & $\begin{array}{c}6 \\
(20.68)\end{array}$ & $\begin{array}{c}3 \\
(10.34)\end{array}$ & \\
\hline & $\begin{array}{l}\text { Retired } \\
\text { Employee }\end{array}$ & $\begin{array}{r}11 \\
(9.4)\end{array}$ & $\begin{array}{c}3 \\
(27.27)\end{array}$ & $1(9.09)$ & $2(18.18)$ & $\begin{array}{c}3 \\
(27.27)\end{array}$ & $\begin{array}{c}2 \\
(18.18)\end{array}$ & \\
\hline & Student & $\begin{array}{l}11 \\
(9.4)\end{array}$ & $\begin{array}{c}3 \\
(27.27)\end{array}$ & $2(18.18)$ & 0 & $\begin{array}{c}4 \\
(36.36)\end{array}$ & $\begin{array}{c}2 \\
(18.18)\end{array}$ & \\
\hline \multirow{3}{*}{$\begin{array}{l}\text { Educ } \\
\text { ation }\end{array}$} & $\begin{array}{l}\text { SSC/Di } \\
\text { ploma }\end{array}$ & $\begin{array}{l}10 \\
(8.5)\end{array}$ & $5(50)$ & $1(10)$ & $1(10)$ & $2(20)$ & $1(10)$ & \multirow{3}{*}{$\begin{array}{r}10 . \\
983 ; 8 ; \\
\mathrm{P}>0.05\end{array}$} \\
\hline & Degree & $\begin{array}{r}52 \\
(44.4)\end{array}$ & $\begin{array}{c}7 \\
(13.46)\end{array}$ & $\begin{array}{c}10 \\
(19.23)\end{array}$ & $\begin{array}{c}11 \\
(21.15)\end{array}$ & $\begin{array}{c}18 \\
(34.61)\end{array}$ & $\begin{array}{c}6 \\
(11.53)\end{array}$ & \\
\hline & $\begin{array}{c}\text { Post- } \\
\text { Graduation }\end{array}$ & $\begin{array}{r}55 \\
(47.0)\end{array}$ & $\begin{array}{c}13 \\
(23.63)\end{array}$ & $\begin{array}{c}12 \\
(21.81)\end{array}$ & $6(10.90)$ & $\begin{array}{c}13 \\
(23.63)\end{array}$ & $11(20)$ & \\
\hline
\end{tabular}

\section{Source: Primary Data}

\section{Conclusion:}

The psychographic segmentation of the customers through VALS (Values Attitude and Lifestyles) is proved with this study and the concerned dimensions are validated as thinkers, believers, achievers, strivers, experiencers and makers towards the eco label awareness.

\section{References}

Barat, S (2010), “Market Segmentation Success-Making it Happen!” Journal of Consumer Marketing, 27(1), 86-87.

Barnett, N.L., (1969), 'Beyond Market Segmentation", Harvard Business Review, January-February,152-166.

Bauer, M, and Auer-Srnka, K.J (2012), "The life cycle concept in marketing research. Journal of Historical Research in Marketing", 4(1), 6896.

Beatty, S.E., Homer, P.M. and Kahle, L.R. (1988). "Problems with VALS in International Marketing Research: An example from An Application of The Empirical Mirror Technique", Advances in Consumer Research, 15,375-38.

Dickson, P.R., \&Ginter, J.L. (1987), "Market segmentation, product differentiation, and marketing strategy". The Journal of Marketing, 10(1), $1-10$.

Domowitz, I, Glen, J, and Madhavan, A (2012), "Market segmentation and stock prices: Evidence from an emerging market,". The Journal of Finance, 52(3), 1059-1085. 
Du Preez, R., Visser, E. M. and Zietsman, L. (2007)."Profiling Male Apparel Consumers: Lifestyle, Shopping Orientation, Patronage Behavior and Shopping Mall Behavior”, Management Dynamics, 16(1), 2-19.

Füller, J., and Matzler, K (2008), "Customer delight and market segmentation: An application of the three-factor theory of customer satisfaction on life style groups". Tourism Management, 29(1), 116-126.

Walsh, G., Hennig-Thurau, T., Wayne-Mitchell, V., and Wiedmann, K.P (2001), "Consumers' decision-making style as a basis for market segmentation".Journal of Targeting, Measurement and Analysis for Marketing, 10(2), 117-131.

Wilkie W.L and Cohen, J.B., (1977), “An Overview of Market Segmentation: Behavioral Concepts and Research Approaches”, Marketing Science Institute Working paper, Cambridge, Massachusetts.

Wind, Y., (1973), "A New Procedure for Concept Evaluation", Journal of Marketing, 37, 2-11.

Worcester, R.M. and Downham, J. (1978), Consumer Market Research Handbook, second edition, New York, Van Nostrand Reinhold Company.

Yankelovich, D., and Meer, D. (2006), "Rediscovering market segmentation". Harvard business review, 84(2), 122.

Ziff, R., (1971), “Psychographics for Market Segmentation”.Journal of Advertising Research, 11(4), 3-9.

Sivakoti Reddy, M. (2019). Impact of RSERVQUAL on customer satisfaction: A comparative analysis between traditional and multi-channel retailing. International Journal of Recent Technology and Engineering. 8(1), pp. 2917-2920.

Sivakoti Reddy, M., Murali Krishna, S.M. (2019). Influential role of retail service quality in food and grocery retailing: A comparative study between traditional and multi-channel retailing. International Journal of Management and Business Research, 2019, 9(2), pp. 68-73

Sivakoti Reddy, M., Venkateswarlu, N. (2019). Customer relationship management practices and their impact over customer purchase decisions: A study on the selected private sector banks housing finance schemes. International Journal of Innovative Technology and Exploring Engineering, 2019, 8(7), pp. 1720-1728.

Addela, S., Sivakoti Reddy, M. (2019).Mobile banking-an empirical analysis on the customer's perception towards mobile banking in determining the customer satisfaction in the state of telangana rural areas. Journal of Advanced Research in Dynamical and Control Systems, 2019, 11(6), pp. 318-321

Vijaya, P., Sivakoti Reddy, M. (2019). A study on the moderating role of trust in determining the green purchase intentions: Empirical evidence from Indian automobile sector. Journal of Advanced Research in Dynamical and Control Systems, 2019, 11(11), pp. 39-47.

Sivakoti Reddy, M., Naga Bhaskar, M., Nagabhushan, A.(2019). Saga of silicon plate: An empirical analysis on the impact of socio economic factors of farmers on inception of solar plants. International Journal of Control Theory and Applications, 2016, 9(29), pp. 257-266.

Manukonda et al. (2019). What Motivates Students To Attend Guest Lectures?.The International Journal of Learning in Higher Education. Volume 26, Issue 1. 23-34 